сільської школи. - Вип. 32. - 2010. - С.215-219. - Режим доступу: http://www.nbuv.gov.ua/portal/ soc_gum/ Ppps/2010_32/files/215-219.pdf 6. Програма 3 англійської мови для професійного спілкування / [Г. Є. Бакаєва, О.А.Борисенко, I. I. Зуєнок та ін.] - К. : Ленвіт, 2005. - 119 с. 7. Програма 3 англійської мови для університетів (інститутів): п'ятирічний курс навчання / [С. Ю. Ніколаєва, М. І. Соловей та ін.] / К. : Британська Рада, Київ. держ. лінгв. ун-т, 2001. - 245 с. 8. Рамкова програма 3 німецької мов для професійного спілкування для вищих навчальних закладів України / [С. М. Амеліна, Л. С. Аззоліні та ін.]. - К. : Гете-інститут, Ленвіт, 2006. - 90 с.

УДК 37.013 .46

Тетяна Дороніна

\title{
КОНТАМІНАЦІЯ ПОНЯТЬ «ОСВІТНІЙ ПРОСТІР» ТА «ОСВІТНЕ СЕРЕДОВИЩЕ» В СУЧАСНОМУ НАУКОВО-ПЕДАГОГІЧНОМУ ДИСКУРСІ
}

Дороніна Т. О. Контамінація понять «освітній простір» та «освітнє середовище» в сучасному науково-педагогічному дискурсі.

У статті проаналізовано проблеми українського освітнього простору в контексті інтеграційних процесів; подано короткий огляд теоретичних проблем, пов'язаних із категоріями «освітній простір» та «освітнє середовище» та викладено нові підходи до їх розуміння.

Ключові слова: інтеграційні процеси, освітній простір, освітнє середовище.

Доронина Т. А. Контаминация понятий «образовательное пространство» и «образовательная среда» в современном научно-педагогическом дискурсе.

В статье проанализированы проблемы украинского образовательного пространства в контексте интеграционных процессов; представлен краткий обзор теоретических проблем, связанных с категориями «образовательное пространство», «образовательная середа», изложены новые подходы к их пониманию.

Ключевые слова: интеграционные процессы, образовательное пространство, образовательная среда.

Doronina T. A. Contamination of the terms «educational space» and «learning environment» in the modern scientific and pedagogical discourse.

In the article problems of Ukrainian education space in the context of integration processes are analyzed. The article gives a review of theoretical problems connected with the category of «educational space» and «educational environment». The article presents new approaches to understanding the educational environment, educational space.

Key words: the integration processes, educational space, educational environment.

Сучасний розвиток вітчизняної системи освіти відбувається за умов невпинного оновлення та перебудови, що приводить до появи низки широко обговорюваних у науковому товаристві проблем. Переважно йдеться про проблеми, пов'язані зі світовими процесами глобалізації та інтеграції освітніх систем. У вітчизняному дискурсі- це пошук шляхів євроінтеграції 3 відповідною кореляцію вітчизняного досвіду із європейськими стандартами освіти. Прагнення України доєднатися до європейського освітнього простору пояснюється науковцями актуалізація значної кількості сучасних проблем. Проте що таке «світовий освітній простір»? 3 чого він складається, як функціонує та розвивається? Тобто «куди» прагне Україна? 
Звісно, узагальнене визначення поняття можна знайти в довідковій літературі: «Світовий освітній простір об'єднує національні освітні системи різного типу та рівня, що значно різняться філософськими й культурними традиціями, рівнем цілей і завдань, якісними станами. Тому варто говорити про сучасний світовий освітній простір як про єдиний організм, що формується і в кожній освітній системі якого наявні глобальні тенденції й збережено розмаїтість» [14, с. 80]. Загальна спрямованість вітчизняної освіти достатньо чітко окреслена нормативно-декларативними документами, у яких світовий освітній простір трактується переважно як «європейський». Однак варто зважати на те, що науковці (А. Ліферов, А. Рєан, Н. Бордовська та С. Розум), говорячи про неоднорідність сучасного освітнього простору (за характером ставлення до інтеграційних процесів), виокремлюють у ньому три типи регіонів: регіони, що $\epsilon$ генераторами ідей (західноєвропейський, американо-канадський та азіатськотихоокеанський); регіони, що позитивно ставляться до інтеграції (країни Латинської Америки); регіони, які інертні в цьому процесі (країни Африки та південної Азії). Очевидно, що Україна, як і інші пострадянські країни, відсутня у цій типології. Причина цього, на думку згаданих вище науковців, полягає в «економічних та соціальних причинах, які порушили послідовність освітніх та інтеграційних процесів» [17].

Говорити про економіко-соціальну стабілізацію України зарано, тому вітчизняна освітня система у своєму русі опинилася на роздоріжжі. Територіально, звісно, наша країна є європейською, проте чи може вона увійти до країн, які є «генераторами ідей». Та якщо Україна позитивно ставиться до інтеграційних процесів, чи варто звертати увагу на ії територіальне розташування (зважаючи на склад країн, що входять до цієї групи)? Отже, очевидно, світовий освітній простір не вимірюється просторовими чинниками, інтеграція до нього не може бути здійснена фрагментарними змінами в навчальних закладах певного освітнього рівня. Проте, обговорюючи злободенні та суперечливі питання щодо євроінтеграційних процесів в освіті, дослідники послуговуються широковживаними поняттями «освітній простір» (далі по тексту - ОП) та «освітнє середовище» (далі по тексту - ОС), інколи ототожнюючи розглядувані категорії.

Про актуальність питання категоріального визначення понять ОП та ОС свідчить значна кількість сучасних наукових публікацій. Це теоретичні напрацювання таких науковців, як I. Арендачук, I. Беккер та Н. Журавчик, Є. Бєлякова, М. Виленський та Є. Мащерякова, Г. Водяненко, Н. Глаголєв, О. Заблоцька, Н. Касярум, В. Козирев, 3. Количева, В. Корнієнко та С. Плахотнюк, С. Кривих, О. Кубасов, Т. Кузнєцова, О. Леонова, I. Маричев та Е. Маліночка, Р. Пономарьов, О. Попов, І. Римарева, О. Романов, В. Слободчиков, Ю. Таратухіна, В. Чепак, I. Чернецький, I. Шендрик, I. Шалаєв та А. Веряєв, О. Швидка, С. Шептицька, В. Ясвін та ін. Автори праць демонструють евристичний потенціал понять ОП та ОС щодо різних аспектів існування / співіснування людини та світу знань.

Та попри суттєву зацікавленість педагогічним товариством проблемою ОП, дослідники (Є. Бєлякова, А. Віряєв, І. Шалаєв та ін.) звертають увагу на відсутність точного визначення цього поняття в низці авторитетних педагогічних словників, що дає підстави зробити висновок про метафоричне використання поняття ОП у контексті освіти [3, с. 13]. На недостатню визначеність понять ОП та ОС звертають увагу й вітчизняні дослідники. Зокрема Н. Касярум наголошує, що цей термін актуалізований у науці саме через євроінтеграційні процеси вітчизняної системи освіти, оскільки ОП «визначає певні характеристики сучасного розвитку системи освіти» та «задає, окрім напряму (що $\epsilon$ звичною і тривіальною характеристикою), ще й інші координати освітнього процесу: можливість зміни напряму, що передбачає свободу вибору 
особистості, існування варіативних способів досягнення кінцевої освітньої мети, реальну можливість зміни етапів освітнього процесу тощо» [6]. Отже, поняття ОП поширене у публікаціях, у яких аналізу піддаються результати впливу глобалізації на освіту, тому найбільш часто тут використовується словосполучення «європейський освітній простір» [4], який має всепоглинаючий зміст. Натомість поняття ОС найчастіше тлумачиться як оточення, у якому безпосередньо здійснюється освітня діяльність. Водночас у педагогічних публікаціях натрапляємо на поступову взаємозамінність понять ОП та ОС, про що пишуть самі науковці: «У педагогіці цей термін (освітній простір. - Т. Д.) може застосовуватися як синонім до терміна «освітнє середовище»») [13].

Mema cmammi. Задля подолання термінологічної та понятійної плутанини вважаємо за необхідне зосередити свою увагу власне на з'ясуванні евристичного потенціалу понять «освітній простір» та «освітнє середовище» в сучасній педагогіці.

До основних завдань віднесено такі: проаналізувати представлені в сучасній науково-педагогічній літературі дефініції понять «освітній простір» та «освітнє середовище»; встановити сутність та логіко-смислові відношення аналізованих понять; визначити можливість та доцільність їх взаємозамінювання в педагогічному дискурсі.

Передовсім зазначимо, що у визначенні характеру співвіднесеного вжитку означених понять використаємо лінгвістичний термін контамінація (від лат. contamination - змішування, схрещування). Філологи підкреслюють, що для появи контамінації необхідна смислова спорідненість слів, яка у випадку із ОП та ОС очевидна.

Насамперед слід зазначити: поняття «простір» та «середовище» $є$ категоріями загальнонаукового знання, що обумовлює звернення до філософського визначення розглядуваних термінів. У довідковій літературі «простір» (поряд із часом) визначається як одна з головних форм буття матерії, яка «характеризує її протяжність, структурність, співіснування і взаємодію елементів в усіх матеріальних системах» [19, с. 541]. Натомість «середовище» представлено в соціальному контексті та тлумачиться як «суспільні, матеріальні та духовні умови існування, формування та діяльності людини» $[19$, с. 651]. Категорія «простору» також пройшла певну генезу смислів та дефініцій: від виключно математичних до соціальних. Проте якщо простір загалом має геометричну (евклідову) будову - тривимірність («з кількісної позиції поняття простору, a точніше просторових координат, дозволяє використовувати термін відносно протяжності або розмірів фізичних тіл, зокрема описувати їх форму і їх конфігурацію, а також відстань між тілами» [9, с. 109]), то простір буття людини розуміється як «простір соціальної діяльності» (В. Виноградський), а отже, як соціальний простір, який $€$ явищем багатовимірним і багатовекторним. На це вказував вже П. Сорокін: «Евклідовий геометричний простір - тривимірний. Соціальний простір - багатовимірний, оскільки існує більше трьох варіантів угрупування людей за соціальними ознаками, які не збігаються один з одним (групування населення за приналежністю до держави, релігії, національності, професії, політичних партій, економічним статусом, походженням, статтю, віком тощо)» [18, с. 300]. Розгортанням думки філософа вважаємо зауваження Н. Міхно: «Соціальний простір як поле соціальної діяльності, що містить сукупність значимих соціальних груп, індивідів, об'єктів у тому чи іншому їх взаємному розташуванні, є базовим елементом суспільної матерії» [12, с. 83]. Отже, у структурі соціального простору (залежно від характеру угрупування та типу соціальних відносин, до яких долучається людина) виділяються підструктури: освітній простір, виробничий простір, родинний простір, побутовий простір тощо. Із цих позицій формулює теоретик освітнього простору/середовища I. Шендрик своє визначення: ОП - «частина 
соціального простору, у межах якого суспільством (державою) здійснюється унормована освітня діяльність» [23, с. 3].

Загальний огляд представлених у науковому дискурсі визначень ОП надає змогу встановити, що ОП розглядають як:

- певну територію, «яка пов'язана з масштабними явищами в галузі освіти: як певна частина соціального простору, у межах якої здійснюється унормована освітня діяльність; як єдність, цілісне утворення в галузі освіти, яке має свої межі, що уточнюються окремо, - світовий освітній простір, міжнародний освітній простір, європейський освітній простір, освітній простір регіону, школи, шкільного класу тощо» [21];

- місие, «що охоплює людину та середовище у процесі їхньої взаємодії, результатом чого є прирощення індивідуальної культури того, хто вчиться» [15, с. 30];

- структуровану систему, що складається з низки елементів: «сукупність освітніх технологій, які застосовуються; керування навчально-виховним процесом; взаємодія 3 зовнішніми освітніми і соціальними інститутами» [16, с. 141].

Отже, очевидно, що до розуміння ОП частиною сучасних науковців покладено власне територіальний принцип, згідно з яким ОП тлумачиться як певна територія, що має спільне освітнє насичення. Це територія, до якої входять держави із відносно однорідною освітньою політикою, законодавчими актами, навчальними установами та стандартами. За таким принципом власне державні інституції є суб'єктами освітньопросторових відносин.

Спроби науковців структурувати ОП призводять до часткового ототожнення поняття із поняттям ОС. Наприклад, ще більш широким та структурованим постає ОП у визначенні, який надає В. Коваль: «Освітнє середовище є сукупністю освітніх інститутів та механізмів реалізації взаємодії між цими інститутами, мас-медіа, що орієнтовані на освіту, громадськість, яка долучена до розв'язання проблем освіти, а також освітні теорії та соціально-педагогічні стереотипи, що панують на цей час та регламентують поведінку людей щодо їхнього ставлення до освіти» [7, с. 94].

Інший (діяльнісний) підхід демонструють дослідники, які розглядають ОП як форму системної взаємодії. Наприклад, І. Шалаєв та О. Веряєв стверджують, що до поняття ОП входять «певна освітня протяжність, структурне існування і взаємодія будьяких можливих освітніх систем, їх компонентів, освітніх подій» [22].

Щодо освітнього середовища, то тут також знаходимо низку визначень, які певним чином збігаються з визначенням ОП:

- «психолого-педагогічна реальність, яка містить спеціально організовані умови для формування особистості, а також можливості задля розвитку, які включені в соціальне і просторово-предметне оточення і які традиційно розглядають як галузь соціального життя і як чинник освіти, що забезпечує педагогічні умови врівноваження досвіду взаємодії учнів із зовнішнім світом і внутрішнім середовищем їх розвитку» [1]; «педагогічна реальність, що характеризується визначеністю, керованістю, структурністю» [11, с. 10];

- «система впливів та умов формування особистості за заданим взірцем, а також можливостей для іiі розвитку, що містяться в соціальному та просторово-предметному оточенні» $[25$, с. 14$]$; «набір певним способом пов' язаних між собою умов, які можуть впливати на освіту людини» [8];

- «система, що акумулює інтелектуальні, культурні, програмово-методичні, організаційні та технічні ресурси та забезпечує формування особистості в її різноманітних 
виявах. При цьому керівництво освітнім середовищем здійснюється опосередковано цільовими настановами суспільства та суб'єктів освітнього процесу» [3, с. 16].

Отже, ключовими для визначення поняття ОС стають «реальність», «впливи» та «умови», за яких відбувається освітня діяльність, спрямована на формування та розвиток особистості.

Слід відзначити існування стійкої тенденції до визначення ОП через поняття «середовища». Прикладом цього $є$ визначення О. Шогоєвої: «Насправді «освітній простір»- це поле взаємодії, навколишнє середовище (курсив наш.- Т.Д.), яке розглядається як «середовище, що запрошує» та визначає свободу вибору для суб' єкта й можливість самотворення, вибірковість взаємодії між середовищем та людиною» [24, c. 96]. Аналогічний підхід демонструє А. Цимбалару, згідно із пропонованим дослідницею визначенням ОП - «спеціально організоване педагогічне середовище як структурована система педагогічних чинників та умов їх розуміння особистістю у процесі іï становлення» [21]. Проте такі визначення значно звужують поняття ОП та зводять його до поняття педагогічного середовища, відкриваючи шлях до обговорення питання: що таке це педагогічне середовище? Уважаємо, це освітнє середовище.

Наявність контамінації аналізованих понять І. Шалаєв та А. Віряєв пояснюють існуванням двох точок зору щодо сутності ОП: субстанціональну та реляційну. Субстанціональний підхід визначає простір як реальність, що існує об'єктивно, у той час як у межах реляційного підходу поняття простору змикається 3 поняттям середовища, у якому відбуваються певні процеси (у цьому випадку - освітній процес). Отже, в реляційному розумінні простір - це система відносин, які утворюються матеріальними об'єктами, що взаємодіють [22]. Ця думка науковців певним чином знаходить своє відбиття в міркуванні А. Цимбалару щодо наявності трьох основних напрямів розуміння феномену «простір»: «об'єктне (картина світу як сукупність зовнішніх об'єктів), суб'єктне (світ є представленістю почуттів та роздумів суб'єктів), діяльнісне (суб'єкт і об'єкт об'єднує діяльність, що створює не лише речі, а й їх смисли)» [21]. Дослідниця підкреслює: «як форма існування об'єктивної реальності простір виражає відношення між наявними об'єктами, визначає порядок їх розташування, щільність, площину, структуру та характеризує всі форми і траєкторії руху матерії» [21]. Отже, простір «виражає відношення», проте не створює їх. На нашу думку, у певному сенсі суперечливим є відокремлення суб'єктного та діяльністного в аспекті соціального простру, це, власне, ті дві точки зору (субстанціональна та реляційна), про які пишуть І. Шалаєв та А. Віряєв.

Дотримуючись субстанціональної точки зору на ОП, уважаємо, що необхідно більш уважно поставитися до культурологічного аспекту проблеми. За сучасних умов зміни культурних парадигм від постіндустріальної на інформаційну розуміння освітнього простору неможливо звести чи до територіального поділу, чи до структурного переформатування. На початку статті було згадано типи сучасних соціальних просторів, які на перший погляд мають територіальну ознаку, проте головне в цьому поділі - ставлення до новітніх (освітніх) ідей та здатність освітніх систем до їх сприйняття та втілення. Ми погоджуємося 3 думкою Н. Рибки, яка, проводячи грунтовний аналіз поняття ОП як загальнонаукової категорії, підкреслювала, що «поняття ОП відбиває переважно внутрішні (педагогічні, психологічні та ін.) зміни в системі освіти, безвідносно до перевлаштовування системи інституційних взаємозв'язків освіти 3 іншими державними, недержавними та міждержавними установами» $[16$, с. 142], що унеможливлює виокремлення в ОП державного чи регіонального рівнів, як-то продовжують робити науковці. Проте ця думка, можливо, потребує певного уточнення. 
Ураховуючи багатовимірність розглядуваних понять, уважаємо за необхідне звернути увагу на доцільність застосування до трактування понять ОП та ОС власне культурологічного підходу. Пошлемося на думку І. Шалаєва та А. Віряєва, які пов'язують появу феномена ОП у педагогічному дискурсі із «переходом суспільства до інформаційної стадії розвитку» [22]. Культурологічний підхід до осмислення феномена ОП дозволяє розглянути сучасні освітні системи білыш широко, як це представлено в цікавому дослідженні О. Волкової, що репрезентує наявні в науці типи ОП саме в аспекті зміни культурних парадигм. Органічними в цьому плані стають такі принципи розвитку ОП: принцип природовідповідності, культуровідповідності, інтеграції, гуманізації, демократизації, диференціації та індивідуалізації [5, с. 180], наявність яких декларується практично в кожному сучасному освітньому документі. 3 позицій цього (культурологічного) підходу «освітнє середовище розглядається як мезо- та мікрорівні освітнього простору, що найбільш тісно пов'язані 3 життєдіяльністю людини, ії формуванням та розвитком» [3, с. 15$]$.

Велика кількість визначень ОП та ОС свідчить, що ці поняття описуються значною кількістю атрибутивних характеристик, які сприяють їхньому зближенню, отже контамінації. Уважаємо, поняття ОС повинно розглядатися як підпорядковане поняттю ОП, відповідно, розглядувані поняття можливо зіставити в категоріях: зміст / форма, локальне / глобальне, динамічне / статичне. Існує суттєва відмінність між поняттями ОС та ОП, обов'язкова присутність (дія / взаємодія) в ОС суб'єктів освітнього процесу. Тому ми дотримуємося точки зору тих науковців, які вважають, що спільним у поняттях «освітній простір» та «освітнє середовище» $є$ «спрямованість на завдання освіти, обидва $\epsilon$ оточенням, зовнішнім щодо суб'єкта освітнього процесу. Середовище передбачає заглибленість у неї, сьогохвилинне або часте використання з неї потоку інформації задля зміни та вдосконалення людського «Я». Натомість освітній простір більшою мірою передбачає не заглибленість, а присутність, простір виконує свої функції в моменти більш критичні чи вирішальні для майбутнього, що пов'язані $з$ доленосним вибором» [22]. Зі свого боку освітній простір може мати низку локальних підпросторів: бібліотека, культурні установи, клуби за інтересами, громадські організації, студентське самоврядування та ін. Кожен із них можливо та доцільно розглядати, як пропонує (слідом за Г. Серіковим) Т. Кузнецова, за низкою координат: 1) нормативно-регулююча, 2) перспективно-орієнтуюча; 3) діяльнісно-стимулююча та 4) комунікативноінформаційна [10, с. 147]. 3 таких позицій виокремлювати в ОП інші види підпросторів (підпростір учнів, батьків, адміністрації), як це пропонують І. Беккер та Н. Журавчик [2, c. 133], здається необгрунтованим, оскільки в цьому випадку скоріше за все йдеться про середовище, оскільки стосується власне суб'єктів освітнього процесу. Отже, достатньо цікава структура ОП, яка описана I. Беккер та Н. Журавчик [2, с. 135], на наш погляд, $є$ структурою освітнього середовища, у якому доцільно та необхідно виокремлювати модулі, запропоновані авторами: навчальний, навчально-виробничий та соціальновиховний.

Отже, освітнє середовище - «функціональна компонента освітнього простору» (I. Чернецький), яка насичує його певним змістом, комплексом засобів (що $\epsilon$ провідниками знань), до якої входять і суб’єкти навчання. («Освітній простір може існувати незалежно від того, хто вчиться. У цьому випадку передбачається присутність того, хто вчиться, в освітньому середовищі, взаємовплив, взаємодія оточення із суб'єктом» [8]). І Із функціональних позицій (за I. Чернецьким) до ОС входять просторова-матеріальна, соціально-особистісна та інформаційно-функціональна складові [20, с. 139]. Із позицій інформаційної насиченості (за О. Бєляковою) головними компонентами ОС стають: 1) проблемно-орієнтовані багаторівневі інформаційні 
(інтелектуальні, культурні, програмно-методичні) ресурси, які містять знання та технології роботи із ними (пошук, збереження, оброблення, застосування); 2) інформаційна інфраструктура, яка забезпечує функціонування та розвиток середовища в ході освітнього процесу [3, с. 16]. I цей перелік можна продовжувати відповідно до кута зору дослідників.

Узагальнюючи сказане вище, вважаємо за необхідне зробити акцент на поглядах тих науковців, які розглядають поняття ОП достатньо широко. І. Шалаєв та А. Веряєв доводять певну тотожність (але не однаковість) понять «освітній простір» та «соціальний інститут» та, зважаючи на глобалізаційні освітні процеси, наголошують: «ставити завдання із формування єдиного соціального інституту освіти для різних незалежних країн - це нонсенс, оскільки є жорстка прив'язка інституту освіти до національно-державного устрою, водночас освітній простір має інші межі, прозорі для ідей, концепцій, методів» [22].

Отже, яким шляхом просувається наша країна? Структурна перебудова соціальних інститутів освіти задля їхньої уніфікації - це сумнівний шлях до світового освітнього простору. Тому видається вкрай необхідним для вітчизняної педагогіки відпрацювання коректного визначення понять «освітній простір» та «освітнє середовище». Це дасть можливість визначити їх структуру, встановити системні зв'язки, а отже, сприятиме побудові сучасної концептуальної моделі вітчизняного освітнього простору. Все це загалом допоможе з'ясувати, до якого саме освітнього простору прагне увійти Україна, i що для цього необхідно зробити на різних (просторових) рівнях, а отже, дозволить вийти за межі суто навчального середовища та запропонувати стратегічне розв'язання злободенних проблем вітчизняної освіти.

\section{Література}

1. Арендачук И. В. Образовательная среда вуза как факткор психологопедагогических рисков [Электронный ресурс]/ И. В. Арендачук// Материалы VII интернет-конференции «Образование в современном мире»: современные парадигмы открытого образовательного пространства. - Саратов. - Режим доступа : http://www.sgu.ru/files/nodes/77385/Arendachuk.pdf 2. Беккер И. Л. Образовательное пространство как социальная и педагогическая категория / И. Л. Беккер, В. Н. Журавчик // Известия ПГПУ им. В. Г. Белинского. - 2009. - №12 (16). - С. 132140. 3. Белякова Е. Г. Социокультурное информационное пространство образования в контексте проблемы формирования личности / Е. Г. Белякова // Вестник Тюменского государственного университета. - 2010. - №5. - С.11-17. 4. Биков В. Ю. Інтеграції системи освіти України у світовий освітній простір і проектний підхід, як ефективний інструмент іiï реалізації / В. Ю. Биков // Професійна освіта: педагогіка і психологія: Українсько-Польський журнал / За ред. І. Зязюна, Н. Ничкало, Т. Левовицького, I. Вільш. - Київ; Ченстохова, 2001. - Випуск III. - С. 65-73. 5. Волкова Е. В. Пространство знаний и современное образовательное пространство / Е.В. Волкова// Мир психологи. - 2012. - №4. - С. 179-185. 6. Касярум Н. В. Освітній простір як характеристика сучасної системи освіти [Електронний ресурс] / Н. В. Касярум // Портал сучасних педагогічних ресурсів. - Режим доступу: http://intellectinvest.org.ua/pedagog_editions_e-magazine_pedagogical_science_arhiv_pn_n1_2008_st_2/

7. Коваль В. А. Теоретический анализ проблемы управления образовательным пространством / В. А. Коваль // Соціальні технології. - 2010. - № 4. - С. 94-97. 8. Козырев В. А. Построение модели гуманитарной образовательной среды / В. А. Козырев // Педагог. - 1999. - №7. - С. 26-32. 9. Кривых С. В. Соотношение понятий «среда» и «пространство» в социокультурном и образовательном аспектах / С. В. Кривых // Мир науки, культуры, образования. - 2011. - № 2 (27). - С. 106-111. 
10. Кузнецова Т. И. Пространство предвузовского математического образования / Т. И. Кузнецова // Научный вестник Московского государственного технического университета гражданской авиации. - 2005. - № 94. - С. 141-148. 11. Леонова О. Образовательное пространство как педагогическая реальность / О. Леонова // Alma mater (Вестник высшей школы). - 2006. - № 1. - C. 36-40. 12. Міхно Н. К. Реконфігурація поняття «соціальний простір»: від модерну до другого модерну/ Н. К. Міхно // Вісник ЛГУ імені Тараса Шевченка. - 2011. - №12 (223). - Т. 2. - С. 8388. 13. Назаренко Ю. А. Формування концептуально-понятійного поля сфери досліджень духовно-релігійних цінностей як необхідних для впровадження в світський освітній простір України [Електронний ресурс] / Ю. А. Назаренко // Гілея: науковий вісник. - 2012. - № 66 - Режим доступу : http://www.nbuv.gov.ua/portal/Soc_Gum/Gileya/ 2012 66/Gileya66/F38_doc.pd. 14. Ортинський В. Л. Педагогіка вищої школи: навч. посіб. [для студ. вищ. навч. закл.] /Електронний ресурс]/В. Л. Ортинський. - К. : Центр учбової літератури, 2009. - 472 с. - Режим доступу: http://pidruchniki.ws/00000000/ pedagogika/pedagogika_vischoyi_shkoli__ortinskiy_vl 15. Пономарев Р. Е. Образовательное пространство как основополагающее понятие теории образования / Р. Е. Пономарев // Педагогическое образование и наука. - 2003. - №1. - С.29-31. 16. Рибка Н. М. Структура поняття «єдиний освітній простір» / Н. М. Рибка // Культура нородів Причерноморья. - 2004. - №51. - С. 141-144. 17. Реан А. А. Психология и педагогика [Электронный ресурс] / А. А. Реан, Н. В. Бордовская, И. С. Розум. - СПб. : Питер, 2002. - 432 c. - Режим доступа: http://www.psyho.ru/library/books/rean-aabordovskaya-n-vrozum-s-i-psixologiya-i-pedagogika/. 18. Сорокин П. Человек. Цивилизация. Общество / П. Сорокин. - М. : Политиздат, 1992. - 543 с. 19. Философский энциклопедический словарь [состав. Л.Ф. Ильичев и др.].- М. : Советская энциклопедия, 1983. - 840 с. 20. Чернецький І. С. Проектування навчальних середовищ на основі фрактальних властивостей їх складових / I. С. Чернецький // Вісник Черкаського університету. - 2012. - №13 (226). - С. 138-143. 21. Цимбалару А. Д. Компонентно-сруктурний аналіз поняття «освітній простір» [Електронний ресурс]/ А.Д. Цимбалару. - Режим доступу: http://www.rusnauka.com/20_PRNiT_2007/Pedagogica/ 23997.doc.htm. 22. Шалаев И. К. От образовательных сред к образовательному пространству: понятие, формирование, свойства [Электронный ресурс] / И.К. Шалаев, А.А. Веряев // Педагог. - 1998. - №4 - Режим доступа : http://www.unialtai.ru/Journal/pedagog/pedagog 4/ articl_1.html 23. Шендрик И. Г. Образовательное пространство субъекта и его проектирование : монография / И. Г. Шендрик. - М. : АПКиПРО, 2003. - 156 с. 24. Шогоева Е. Ю. Образовательное пространство и самореализация обучаемых в системной парадигме / Е. Ю. Шогоева // Вестник Московского государственного областного университета. Серия: Психологические науки. - 2012. - №1. - C. 96-100. 25. Ясвин В. А. Образовательная середа: от моделирования к проектированию / В. А. Ясвин. - М. : Смысл, 2001. - 365 с.

\section{МЕТОД ПРОЕКТІВ У НАВЧАЛЬНОМУ СЕРЕДОВИЩ}

Зеленкова Н. І., Голоденко О. М. Метод проектів у навчальному середовищі.

У статті розкривається сутність методу проектів у досягненні методичної мети. Висвітлено сутність проекту та етапи роботи над ним. Розглянуто причини застосування проектного навчання, які сприяють виробленню різних рис. Приділено увагу проектно- 